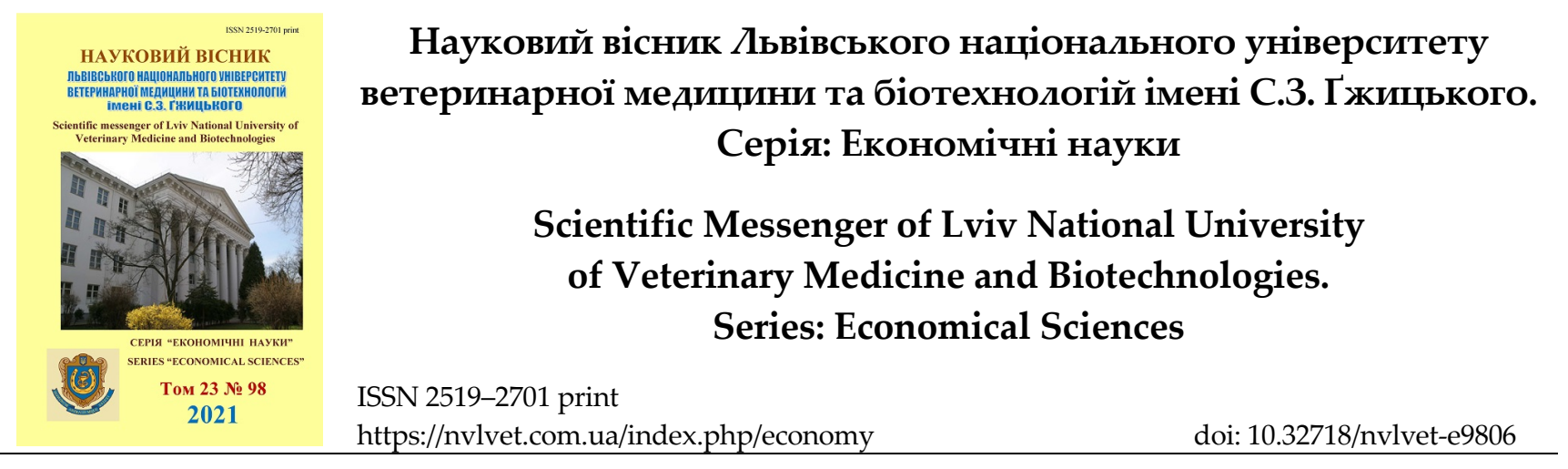

UDC: 330.322 .14

\title{
Features of the methodology for assessing budget efficiency investment projects
}

\author{
R. M. Myniv ${ }^{1}$, V. O. Ivashkiv², H. M. Mokrytska ${ }^{1}$ \\ ${ }^{1}$ Stepan Gzhytskyi National University of Veterinary Medicine and Biotechnologies Lviv, Lviv, Ukraine \\ ${ }^{2}$ Lviv Polytechnic National University, Lviv, Ukraine
}

Article info

Received 16.10.2020

Received in revised form 29.11.2020

Accepted 01.12.2020

Stepan Gzhytskyi National University of Veterinary Medicine and Biotechnologies Lviv, Pekarska Str., 50, Lviv, 79010, Ukraine.

Tel.:+38-050-614-89-82 E-mail:muniv@ukr.net

Lviv Polytechnic National University,

Stepana Bandera Str., 12, Lviv 79000, Ukraine.

E-mail:

viktoriaivashkiv08@gmail.com
Myniv R. M., Ivashkiv, V. O., \& Mokrytska, H. M. (2021). Features of the methodology for assessing budget efficiency investment projects. Scientific Messenger of Lviv National University of Veterinary Medicine and Biotechnologies. Series: Economical Sciences, 23(98), 40-44. doi: $10.32718 /$ nvlvet-e9806

The analysis of current regulations shows that only a few indicators (budgetary effect) are used to assess the budget efficiency of investment projects in Ukraine, and the decision on financing is not made from it. As a result, it is necessary to raise the issue of introducing an additional system of indicators for assessing the effectiveness of investment projects, which characterize the return on investment of budget funds. Thus, the purpose of this study is to develop proposals for improving the methodology for assessing the budget effectiveness of investment projects. The main indicator for assessing the effectiveness of projects that provide state or regional financial support is the budgetary effect. Budget effect is the main indicator of budget efficiency used to justify the decision to finance the project, which is often defined as the difference between inflows and outflows of budget funds, taking into account discounting. The paper proposes to introduce additional indicators to assess the budget efficiency of the investment project, in addition to the payback period of state support. Absolute budget effect. which will be calculated in the form of two indicators: taking into account and without taking into account loans to banks under government guarantees. This calculation is justified, as the budget effect may be understated by including bank loans in the definition of this indicator, while the state budget may not incur costs under its guarantee obligations. Absolute budgetary effect, which characterizes the total amount of funds that the country's budget will receive as a result of the project. Relative budget effect, which characterizes the ratio of budget investments to the investment project and additional revenues to the budget. Budget profitability - shows how many monetary units the project implementation brings per unit of budget funds spent. Due to the fact that this indicator is based on the indicator of the absolute budgetary effect, the calculation of this indicator will be calculated taking into account and without taking into account bank loans issued under government guarantees. The authors have developed some modifications to the calculations for assessing the budget efficiency of investment projects, as well as the calculation of indicators of budget efficiency of projects that characterize the return on investment: absolute budget effect, relative budget effect (indirect and direct), budget profitability.

Key words: investment project, evaluation, methodology, budget efficiency.

\section{Особливості методики оцінки бюджетної ефективності інвестиційних проектів}

\author{
Р. М. Минів ${ }^{1}$, В. О. Івашків ${ }^{2}$, Г. М. Мокрицька ${ }^{1}$ \\ 1Львівський національний університет ветеринарної медицини та біотехнологій імені С. З. Гэжицького, м. Львів, \\ Україна \\ ${ }^{2}$ Національний університет “Львівська політехніка”, м. Львів, Украӥна
}

\footnotetext{
Аналіз чинних нормативно-правових актів показує, ще з оиінки бюджетної ефективності інвестииійних проектів в Украйні $і$ використовується лише декілька показників (бюджетний ефект), і рімення про фінансування виноситься не з нього. Внаслідок цього варто ставити питання про впровадження додаткової системи показників оцінки ефективності інвестиційних проектів,
} 
щุo характеризують дохідність вкладення бюджетних коштів. Таким чином, метою даного дослідження є розробка пропозииій щзодо вдосконалення методики оцінки бюджетної ефективності інвестиційних проектів. Основним показником оцінки ефективності проектів, які передбачають державну або регіональну фінансову підтримку, є бюджетний ефект. Бюджетний ефект - основний показник бюджетної ефективності, шио використовується для обтрунтування рішення про фінансування проекту, який найчастіше визначається як різниия між притоками та відтоками бюджетних коттів з урахуванням дисконтування. В роботі запропоновано для очінки бюджетної ефективності інвестиційного проекту, крім терміну окупності державної підтримки, запровадити додаткові показники. Абсолютний бюджетний ефект. який розраховуватиметься у вигляді двох показників: з урахуванням та без урахування кредитів банкам під гарантії уряду. Даний розрахунок обтрунтований, оскільки бюджетний ефект може бути занижений за рахунок включення кредитів банків у визначення даного показника, у той час як державний бюджет може $і$ не зазнати витрат за свойми гарантійними зобов'язаннями. Абсолютний бюджетний ефект, щуо характеризує загальну суму коштів, яку отримає бюджет країни в результаті реалізації проекту. Відносний бюджетний ефект, який характеризує співвідношення бюджетних вкладень до інвестииійного проекту та додаткових надходжень до бюджету. Бюджетна рентабельність - показує, скільки грошових одиниць приносить реалізація проекту на одиницю витрачених бюджетних коштів. У зв'язку з тим, щзо ией показник трунтується на показнику абсолютного бюджетного ефекту, розрахунок иього показника розраховуватиметься з урахуванням та без урахування кредитів банків, виданих під гарантії уряду. Авторами розроблена деяка видозміна розрахунків з оиінки бюджетної ефективності інвестиційних проектів, а також розрахунок показників бюджетної ефективності проектів, ицо характеризують дохідність вкладення коштів бюджету: абсолютний бюджетний ефект, відносний бюджетний ефект (непрямий та прямий), бюджетна рентабельність.

Ключові слова: інвестиційний проект, оцінка, методика, бюджетна ефективність.

\section{Вступ}

Інвестиційна діяльність підприємства об’єктивно здійснюється в умовах невизначеності, яка має прояв у неможливості однозначного прогнозування майбутніх подій та спричиняє появу ризиків, оцінка яких $є$ доволі трудомістким та складним завданням. Вагомою причиною існування невизначеності, що ускладнює процес управління економікою підприємства, $\epsilon$ недостатній обсяг інформації, іiі неповнота та/або неточність, про актуальний i перспективний стан внутрішнього та зовнішнього середовища інвестиційного проєкту. Недосконалість інвестиційної політики підприємства та нераціональне використання ним залучених інвестиційних коштів стримують розвиток вітчизняної економіки та ставлять під загрозу інвестиційну привабливість українських підприємств. Оскільки існування ризику не дає змоги з точністю до $100 \%$ визначити майбутній стан інвестиційного проєкту, прийняття управлінських рішень повинно базуватися на якісній оцінці ефективності інвестиційної діяльності (Hulyk \& Horb, 2020).

Аналіз чинних нормативно-правових актів показує, що з оцінки бюджетної ефективності інвестиційних проектів в Україні і використовується лише декілька показників (бюджетний ефект), і рішення про фінансування виноситься не 3 нього. Внаслідок цього варто ставити питання про впровадження додаткової системи показників оцінки ефективності інвестиційних проектів, що характеризують дохідність вкладення бюджетних коштів. Таким чином, метою даного дослідження $\epsilon$ розробка пропозицій щодо вдосконалення методики оцінки бюджетної ефективності інвестиційних проектів.

Теоретичні та практичні аспекти проблеми визначення ролі інвестицій в економічному зростанні країни досліджували такі загальновідомі зарубіжні вчені, як Дж. Бейлі, М. Д. Джонк, Дж. М. Кейнс, У. Шарп та інші. Питання формування інвестиційного забезпечення економіки країни розглядається також у наукових працях вітчизняних вчених, серед яких варто виділити доробки таких українських учених, як I. Бланк, Т. Місяць, А. Пересада, Ю. Ткаченко, В. Федоренко та інших.
Оцінювання ефективності інвестиційної діяльності відіграє найважливішу роль при обгрунтуванні і виборі можливих об'єктів інвестування. Наскільки об'єктивно проведена ця оцінка, залежать прийняття вірного інвестиційного рішення, терміни повернення вкладених інвестицій, розвиток фірми, галузі, регіону, суспільства. Обмеженість бюджетних ресурсів і відмова від політики централізованого фінансування розвитку визначають пошук альтернативних шляхів активізації інвестиційної діяльності та залучення інвестиційних ресурсів (Myniv, 2019).

Питання інвестиційного забезпечення суб'єктів господарювання досить часто $\epsilon$ предметом наукових досліджень, оскільки саме інвестиційні ресурси визначаються важливими розвитку, підприємств, галузей та всієї економіки, а інвестиційна діяльність здатна впливати на основи господарської діяльності, різного роду перетворення та розвиток суспільства загалом. Термін "інвестиції” та його розмаїття визначень у літературі пояснюється широтою рис цієї непростої економічної категорії. У загальному значенні у сучасній економічній теорії процес інвестування розуміється як вкладення капіталу для забезпечення його зростання, оскільки латинське слово "invest" - означає “вкладати" (Dunska \& Besarab, 2019).

Мета дослідження полягає у виявленні особливостей методики оцінки бюджетної ефективності інвестиційних проектів

\section{Матеріал і методи досліджень}

Теоретичним і методологічним підгрунтям дослідження $€$ фундаментальні надбання сучасної економічної науки, доробок вітчизняних вчених щодо оцінки бюджетної ефективності інвестиційних проектів . Дослідження виконували на підставі застосування загальнонаукових методів і прийомів: аналізу та синтезу - для оцінювання впливу окремих чинників та показників оцінки бюджетної ефективності інвестиційних проектів; експертних оцінок - для формування системи показників та визначення їх вагомості під час оцінювання ефективності інвестиційних проектів; абстрактно-логічний - для теоретичних узагальнень та формування висновків. 


\section{Результати та їх обговорення}

Держава відіграє вагому роль у формуванні інвестиційного клімату в країні. Дія державних органів направлена на створення сприятливих умов для інвестиційної діяльності аграрних підприємств шляхом прийняття й впровадження в дію нормативноправових документів щодо регулювання та залучення інвестиційних вкладень для ефективного розвитку вітчизняної економіки (Myniv \& Mokrytska, 2020).

Основним показником оцінки ефективності проектів, які передбачають державну або регіональну фінансову підтримку, є бюджетний ефект (Бt). Для року $\mathrm{t}$ здійснення проекту він визначається як перевищення доходів відповідного бюджету (Дt)над витратами $\left(\mathrm{Bt}_{\mathrm{t}}\right.$ унаслідок реалізації проекту:

$$
\bar{b}_{t}=Д_{t}-B_{t}
$$

Показники бюджетної ефективності розраховуються на підставі визначення потоку бюджетних коштів.

До надходжень для розрахунку бюджетної ефективності належать:

- надходження від податків, зборів та інших обов'язкових платежів;

- кошти від сплати за отримання ліцензій, проведення конкурсів і тендерів на розвідку, будівництво та експлуатація об'єктів

- погашення кредитів, виданих з відповідного бюджету; - плата за надання кредиту та/або державної гарантії виконання зобов'язань юридичних осіб - резидентів; - дивіденди.

До видатків бюджетних коштів належать:

- надання коштів для викупу державою акцій додаткових емісій або внесення додаткових вкладів до статутних капіталів господарських товариств, у яких державі належать корпоративні права;

- надання компенсації сум відсоткових ставок за користування кредитом;

- надання бюджетних коштів на безоплатній основі;

- бюджетні дотації, пов'язані з проведенням певної цінової політики і забезпеченням дотримання певних соціальних пріоритетів (Pro zatverdzhennia Metodychnykh ..., 2012; Pro zatverdzhennia Poriadku..., 2012).

Варто також зазначити, що у нормативноправових документах також визначено показники, розрахунок яких необхідний для оцінки бюджетної ефективності інвестиційних проектів:

1) Бюджетний ефект - основний показник бюджетної ефективності, що використовується для обгрунтування рішення про фінансування проекту, який найчастіше визначається як різниця між притоками та відтоками бюджетних коштів з урахуванням дисконтування та розраховується за формулою (2):

$$
Б E=\sum_{t=1}^{T}\left(H \Pi_{t}-P \sigma i H_{t}\right) \times K_{\partial}
$$

де, БЕ - бюджетний ефект від інвестиційного проекту;
$\mathrm{HП}_{\mathrm{t}}$ - податкові надходження до бюджету за $\mathrm{t}$ рік; Рбin - кошти бюджету, передбачувані на державну підтримку інвестиційного проекту в t році;

$\mathrm{K}_{\partial}$ - коефіцієнт дисконтування інвестиційного проекту.

Бюджетний ефект від реалізації інвестиційного проекту має бути більшим за нуль для того, щоб визнати проект ефективним (2).

Індекс бюджетної ефективності (він же - бюджетна ефективність, бюджетна рентабельність, коефіцієнт бюджетної ефективності, відносний бюджетний ефект), який визначається як відношення суми податкових та інших обов'язкових платежів до бюджету у зв'язку з реалізацією інвестиційного проекту до суми коштів, що надається державної підтримки. Розрахунок показника представлений у формулі (3):

$$
\mathrm{I}_{б е}=\frac{\sum H \mathrm{H}_{t} \times K_{\partial}}{\sum \mathrm{P} \tilde{\mathrm{n}} \Pi_{t} \times \mathrm{K}_{\partial}}
$$

де, І $_{\text {бе }}$ - індекс бюджетної ефективності.

Проект вважається ефективним, якщо він перевищує одиницю.

3) Індекс прибутковості інвестицій бюджету (бюджетна ефективність), що розраховується за такою формулою (4):

$$
\mathrm{I}_{\text {дб }}=\frac{\mathrm{BE}}{\sum \mathrm{P}_{\mathrm{j}} \mathrm{in} \times \mathrm{K}_{\partial}}
$$

де, $\mathrm{I}_{\text {дбі }}$ - індекс прибутковості інвестицій бюджету

На підставі дисконтованих бюджетних потоків здійснюється розрахунок терміну окупності державної підтримки проекту. На нашу думку, аналіз бюджетної ефективності інвестиційного проекту має бути розширений, оскільки, з боку держави надаються додаткові субсидії підприємствам, які реалізують інвестиційні проекти у вигляді бюджетних позик та позик із коштів республіканського бюджету, відшкодування частини відсотків із коштів республіканського бюджету за користування кредитами, надання коштів 3 інноваційного фонду, пільг за податковими та митними платежами, проте - такого виду стимули мають застосовуватися не до всіх інвестиційних проектів, а лише до тих, що принесуть додатковий дохід до державного бюджету країни.

Ми пропонуємо для оцінки бюджетної ефективності інвестиційного проекту, крім терміну окупності державної підтримки, запровадити додаткові показники.

Абсолютний бюджетний ефект. який розраховуватиметься у вигляді двох показників: 3 урахуванням та без урахування кредитів банкам під гарантії уряду. Даний розрахунок обгрунтований, оскільки бюджетний ефект може бути занижений за рахунок включення кредитів банків у визначення даного показника, у той час як державний бюджет може і не зазнати витрат за своїми гарантійними зобов'язаннями. Абсолютний бюджетний ефект, що характеризує загальну суму коштів, яку отримає бюджет країни в 
результаті реалізації проекту, розраховується за такою формулою (5):

$$
\mathrm{БE}_{a l}=\sum_{\mathrm{t}=1}^{\mathrm{T}}\left(Д_{\sigma}-\mathrm{P}_{\sigma}-\mathrm{KБгар)}\right) \times \mathrm{K}_{\partial}
$$

де, БЕ ${ }_{a 1}$ - абсолютний бюджетний ефект;

Дб - додаткові надходження до бюджету під час реалізації інвестиційного проекту у період $\mathrm{t}=1,2,3, \ldots, \mathrm{T}$; $\mathrm{P}_{\sigma}$ - кошти бюджету, створені задля державну підтримку інвестиційного проекту у період $\mathrm{t}=1,2,3, \ldots, \mathrm{T}$; $\mathrm{K}_{\partial}$ - коефіцієнт дисконтування.

Відповідно, абсолютний бюджетний ефект за винятком кредитів банків під гарантії уряду розраховуватиметься таким чином за формулою (6):

$$
\mathrm{БE}_{a 2}=\sum_{\mathrm{t}=1}^{\mathrm{T}}\left(Д_{\sigma}-\mathrm{P}_{\sigma}-\mathrm{KБгар)}\right) \times \mathrm{K}_{\partial}
$$

де, КБ гар - кредити банків, гарантовані урядом.

Цілком очевидно, що цей показник має бути більшим за нуль для того, щоб проект був ефективним при фінансуванні інвестиційного проекту бюджетними коштами. Якщо БЕ $\mathrm{E}_{a}>0$, то інвестиційний проект принесе бюджетний ефект, і гроші, вкладені за рахунок коштів бюджету, згодом окупляться за рахунок податкових надходжень; якщо $\mathrm{БE}_{a}=0$, то реалізація інвестиційного проекту окупить витрати бюджету, проте не дасть додаткового ефекту; якщо $\mathrm{БE}_{a}<0$, то вкладені в інвестиційний проект бюджетні кошти не лише не принесуть додаткових надходжень до бюджету, а й не відшкодують видатків.

Відносний бюджетний ефект характеризує співвідношення бюджетних вкладень до інвестиційного проекту та додаткових надходжень до бюджету та розраховується за формулою (7):

$$
\mathrm{EE}_{\mathrm{o}}=\frac{\sum_{t=1}^{T} \mathrm{P}_{6}}{\sum_{t=1}^{T} A_{6}}
$$

де, БЕ

Поділяємо відносний бюджетний ефект додатково на непрямий та прямий, розподіляючи витрати, які несе бюджет, на непрямі та прямі. Так, до прямих витрат ми відносимо бюджетні кошти, що надаються на реалізацію інвестиційного проекту у вигляді бюджетних позичок, позик, субсидій, коштів з фондів, до непрямих - кошти, недоотримані бюджетом того чи іншого рівня внаслідок надання податкових та митних пільг підприємствам, які реалізують інвестиційний проект. Таким чином, розділяючи бюджетний ефект на непрямий та прямий, ми зможемо оцінити внесок кожного 3 них. Розрахунок даних показників буде здійснюватися за такими формулами: (8) та (9):

$$
\mathrm{BE}_{\mathrm{OII}}=\frac{\sum_{\varepsilon=1}^{T} \Pi \mathrm{P}_{\mathrm{G}}}{\sum_{t=1}^{T} \mathrm{H}_{6}}
$$

де, БЕ ПР

$$
\mathrm{EE}_{\mathrm{OK}}=\frac{\sum_{t=1}^{T} \mathrm{KP}_{6}}{\sum_{t=1}^{T} A_{6}}
$$

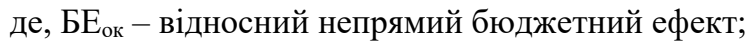
КР ${ }_{б}-$ непрямі видатки бюджету.
Бюджетна рентабельність - показує, скільки грошових одиниць приносить реалізація проекту на одиницю витрачених бюджетних коштів. У зв'язку 3 тим, що цей показник грунтується на показнику абсолютного бюджетного ефекту, розрахунок цього показника розраховуватиметься з урахуванням та без урахування кредитів банків, виданих під гарантії уряду (формули (10):

$$
R_{\mathrm{b} 1}=\frac{\mathrm{BE}_{\mathrm{a} 2}}{\Sigma_{\hat{\varepsilon}=1}^{T}\left(\mathrm{P}_{\mathrm{\sigma}} \times \mathrm{K}_{Q}\right.}
$$

де, $\mathrm{R}_{\mathrm{b} 1}$ - бюджетна рентабельність проекту.

Бюджетна рентабельність за винятком кредитів під гарантії уряду розраховується так (формула (11)):

$$
R_{\mathrm{D} 2}=\frac{\mathrm{EE}_{\mathrm{a} 2}}{\sum_{t-1}^{T^{T}}\left(\mathrm{P}_{6}-\mathrm{KE}_{\mathrm{rap}}\right) \times \mathrm{K}_{\partial}}
$$

де, $\mathrm{R}_{\text {Б2 }}$ - бюджетна рентабельність проекту за винятком кредитів банків під гарантії уряду.

Економічна оцінка ефективності інвестицій характеризує ефективність реалізації інвестиційного проекту $з$ точки зору суспільства, за цінами світових ринків на ресурси і продукцію. Залежно від виду оцінки використовуються певні методи оцінки ефективності інвестицій. У світовий практиці застосовуються різноманітні методи оцінки ефективності інвестицій,, які в останні роки набули поширення в Україні. Завдяки цим методам здійснюється інвестиційний аналіз проектів, тобто оцінюється і зіставляється їх інвестиційна привабливість. Головною метою такого аналізу є виявлення і використання можливостей підвищення їх ефективності.

\section{Висновки}

Отже, бюджетна ефективність - це система показників, що відображають вплив реалізації інвестиційного проекту на бюджети різних рівнів унаслідок надання державної підтримки у різних, обумовлених законодавством, формах. Нами розроблена деяка видозміна розрахунків з оцінки бюджетної ефективності інвестиційних проектів, а також розрахунок показників бюджетної ефективності проектів, що характеризують дохідність вкладення коштів бюджету: абсолютний бюджетний ефект, відносний бюджетний ефект (непрямий та прямий), бюджетна рентабельність.

Перспективи подальших досліджень. Враховуючи викладене вище подальші наукові дослідження варто спрямувати на конкретизацію процедур щодо удосконалення методики оцінки бюджетної ефективності інвестиційних проектів

\section{References}

Dunska, A. R., \& Besarab, K. M. (2019). Investytsiine zabezpechennia rozvytku mizhnarodnoi diialnosti pidpryiemstva. Ekonomichnyi visnyk NTUU "KPI", 16, 340-350 doi: 10.20535/2307-5651.16.2019.182741 (in Ukrainian).

Hulyk, T. V., \& Horb, Ye. Yu. (2020). Metody otsinky investytsiinykh proiektiv $\mathrm{z}$ urakhuvanniam ryzykiv $\mathrm{V}$ umovakh nevyznachenosti. Vcheni zapysky TNU imeni V. I. Vernadskoho. Seriia: Ekonomika i 
upravlinnia, 31(6(70), 99-109. doi: 10.32838/25234803/70-6-17 (in Ukrainian).

Myniv, R. M. (2019). Metodychni pidkhody do otsinky investytsiinoi pryvablyvosti silskohospodarskykh pidpryiemstv Naukovyi visnyk LNUVMB imeni S.Z. Gzhytskoho. Seriia: Ekonomichni nauky, 21(93), 6369. doi: 10.32718/nvlvet-e9313 (in Ukrainian).

Myniv, R. M., \& Mokrytska, H. M. (2020). Investytsiine zabezpechennia efektyvnoho rozvytku pidpryyemstv APK Lvivskoi oblasti. Naukovyi visnyk LNUVMB imeni S. Z. Gzhytskoho. Seriia: Ekonomichni nauky, 22(96), 28-34. doi:10.32718/nvlvet-e9605 (in Ukrainian).
Pro zatverdzhennia Metodychnykh rekomendatsii $\mathrm{z}$ rozroblennia investytsiinoho proektu, dlia realizatsii yakoho mozhe nadavatysia derzhavna pidtrymka. Nakaz Ministerstva ekonomichnoho rozvytku i torhivli Ukrainy vid 13.11.2012 № 1279 . URL: https://zakon.rada.gov.ua/rada/show/v127973112\#Text (in Ukrainian).

Pro zatverdzhennia Poriadku ta kryteriiv otsinky ekonomichnoi efektyvnosti proektnykh (investytsiinykh) propozytsii ta investytsiinykh proektiv. Postanova Kabinetu Ministriv Ukrainy vid 18.07.2012 № 684. URL: $\quad$ https://zakon.rada.gov.ua/rada/show/684-2012p\#n31 (in Ukrainian). 